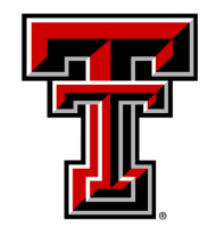

TEXAS TECH UNIVERSITY

Libraries"

\title{
Adapting Service Quality Concepts to ACAdemic LibRaries
}

\section{The Texas Tech community has made this publication openly available. Please share how this access benefits you. Your story matters to us.}

\begin{tabular}{|l|l|}
\hline Citation & $\begin{array}{l}\text { Quinn, B. (1997, September). Adapting service quality concepts to } \\
\text { academic libraries. Journal of Academic Librarianship, 23(5), 359. } \\
\text { https://doi.org/10.1016/S0099-1333(97)90033-1 }\end{array}$ \\
\hline Citable Link & $\underline{\text { http://hdl.handle.net/2346/503 }}$ \\
\hline Terms of Use & $\underline{\text { CC BY-NC-ND }}$ \\
\hline
\end{tabular}




\section{University Libraries \\ Libraries Faculty Research}

Texas Tech University

Year 2007

\section{Adapting Service Quality Concepts to Academic Libraries}

Brian A. Quinn

Texas Tech University, brian.quinn@ttu.edu

This paper is posted at eScholarship Repository.

http://esr.lib.ttu.edu/lib_fac_research/26 
In recent years, both the library profession and the larger educational community have focused increasing attention on a model of management commonly referred to as service quality. The concept of service quality is somewhat elusive and resists easy definition, but essentially it emphasizes customer satisfaction as its primary objective. More traditional measures of academic library quality such as collection size are considered to be of secondary importance. 1

One example of this growing interest in service quality concepts by librarians was the recent program featured at the 1996 American Library Association Convention, sponsored by RASD, the Reference and Adult Services Division of ALA. The program, called "Great Service Now: Framework for Action," featured Dr. Leonard Berry, who holds the J.C.Penney Chair of Retail Studies at Texas A\&M University. Professor Berry, who is the author of several books on quality service, was described by one of the speakers on the program as the foremost authority on quality service.

The Rationale For Service Quality

Prior to introducing Dr. Berry, RASD president Mary Lou Goodyear neatly summarized some of the reasons for the newfound interest of librarians in service quality. The role and purpose of the library are being questioned by policy makers. Increasingly, libraries are being called upon by local, state and national governing bodies to justify their value to the public in a time of budgetary pressures, dwindling public funding, and growing competition from other public institutions such as hospitals and prisons. As more people ask "what are libraries good for?" libraries are subject to increasing scrutiny and accountability. Libraries are being called upon to demonstrate their contribution as 
never before. By providing a perspective of people as customers, the service quality model offers a new concept of libraries.

Dr. Berry elaborated even further. Using the rhetoric of business, he warned that America's libraries are losing market share in what he termed "the information age." Berry believes this is a period in which libraries should be flourishing, because it is characterized by a growing need for education and information on the part of the general populace. He stated that libraries are declining in popularity while the popularity of books is growing. As an example, he mentioned the success of the huge bookstore chain Barnes and Noble, which he said has improved the appeal of booksellers.

According to Berry, huge bookstore chains are not the only threat to libraries. The internet itself is a key competitor. Not only can customers purchase books online at outlets such as the Amazon Web site, but the internet has become a user's personal library, or in Berry's words, a "library in a PC." The user no longer has to go to the traditional library, because he can access information more conveniently from his personal computer.

Faced with such competition, Berry is convinced that there must be a change in how libraries market themselves. The situation is analogous to the post office facing the threat from Federal Express. The way libraries can thrive is by delivering excellent customer service. This could mean anything from creating a drive-up window, to displaying books and information as products, to serving customers coffee from an antique wooden bar.

Librarians must begin to think of themselves as retailers do, and realize that theirs is not just a business but an interpersonal business, a "people" business. Like companies, 
libraries must strive to increase market share. They can do so utilizing three methods: by attracting new customers, by doing more business with existing customers, and by reducing the loss of customers.

Berry then went on to explain that librarians can increase market share by creating what he calls "multiple listening posts." These are means by which librarians can listen not only to external customers but also internal customers and even competitor's customers. Listening to the library's internal customers (colleagues in other departments) can reveal internal obstacles to service provision, while paying attention to the competition's customers will enable one to discover how competitors provide value.

There are many ways a library can survey its customers. Libraries can conduct transactional surveys, which are surveys conducted immediately following some transaction that occurs in the library. Other ways Berry mentioned included conducting focus group interviews, asking customers to sit on advisory panels, and establishing an actual or virtual customer complaint box, to capture criticisms, comments, and inquiries. It is also important to conduct total market surveys, in which competitors are surveyed, and to utilize employee field reporting, to gather feedback about what customers are saying to employees in the field.

The overall quality of service can be improved in several ways. First, by measuring not just the customer's perception of service, but customer's service expectations. Second, by improving service and lowering costs. Berry was careful to point out that improving service and lowering costs might seem like mutually exclusive objectives, but that they can actually work in tandem. It is possible to do both by eliminating any non-value adding processes in the library, by improving productivity 
through technology, and by redesigning the service system to be simpler. As an example, he mentioned the ability of Taco Bell to achieve better service by moving its food preparation operations offsite, which expanded seating capacity for customers and allowed employees to focus on serving them.

A third way libraries can enhance service quality is by showing customers respect. Berry is convinced that there is a customer respect deficit in the U.S. He pointed out that many of the most common customer complaints regarding service, such as customer disparagement by employees, or being forced to wait for service, could be remedied by basic attitudinal changes by service staff.

The final way that a library can improve the customer experience is by paying greater attention to the overall atmosphere or ambiance that business is conducted in. As an example, Berry mentioned the Tattered Cover Bookstore in Denver. It is popular with customers not just for its outstanding selection of books, but also for its ambiance. Customers love its antique, comfortable feel, and it is the policy of the store to allow customers to sit all day and read if they wish.

Berry concluded his address by declaring that libraries must compete for customers by offering something valuable and then delivering it in a way that creates more value. Libraries must therefore define value and then create it. In an era of Darwinian competition for resources, libraries must compete harder and more passionately if they are to survive. Librarians must ask themselves, "if our library were to disappear from the landscape overnight, would we be missed?"2

\section{$\underline{\text { Some Limitations of the Service Quality Model }}$}


What are librarians to make of Dr. Berry's analysis and prescription for the current state of libraries? Some of the assumptions upon which his arguments are based seem at least open to question. By examining these in more detail it might be possible to arrive at a clearer understanding of some of the limitations and possibilities that the service quality model holds for academic libraries. For example, it may be true that libraries in this country as losing market share and that their popularity is decreasing. There is some evidence to suggest that this is not the case, however. One recent study reported that two out of three Americans go to libraries each year.3

Another assumption Berry makes that seems debatable is whether libraries, particularly academic libraries, are in direct competition with large book store chains. The idea that students may be going to the big chains to purchase books instead of going to the library to borrow them is open to question simply because the cost to the student would be prohibitive. Indeed, in the author's experience students frequently inquire at the reference desk as to whether the library owns copies of the textbooks a professor has assigned for their class, even though copies are readily available at the campus bookstore. It is apparent that many of these students are trying to avoid the cost of purchasing these often expensive books themselves if they can possibly obtain them at the library.

The other major threat to libraries that Berry mentioned in his address was the internet. It is true that the internet has grown rapidly in the past few years, and will likely continue to do so in the future. Yet it may be something of an exaggeration to say that the internet now constitutes a "library in a PC." Some of the many reasons why this may not be true include the unscholarly nature of much of the content to be found on the internet, the lack of digitized books available at present, and the difficulty of conducting scholarly 
research on the internet due to the fact that many of its resources are uncataloged and are subject to frequent shifts in location. Internet access itself is often difficult or frustratingly slow because of technical problems or heavy usage. 4 This is not to say that the internet does not have the potential at some point in the future to rival academic libraries as the key of source of scholarly information, only to note that it does not now. Perhaps it might be more reasonable to say that, at present, they complement one another.

Although Dr. Berry did not mention them in his address, other observers have suggested that commercial document delivery services might pose an additional threat to academic libraries.5 The ease and convenience of being able to order an article from a service like CARL Uncover is undeniable. The problem is that the cost per article can typically run ten or twenty dollars or more, depending on the length. Many students balk at paying such a price for a single article, thus limiting the popularity of such services, and their potential threat.

\section{Service Quality and the Academic Library Environment}

There is another bigger assumption that Berry makes that is open to question. It is that the overall service quality model can be imported from the commercial environment of business to the non-commercial environment of the academic library without at least some adaptation. Berry makes no allowance for the fact that the educational setting is different from the corporate one. The assumption appears to be that a model that works in one sector will readily translate into another, but this is not necessarily so. 
Some of the difficulties involved in applying service quality concepts to nonprofit environments have been noted in a recent article about adapting TQM to government agencies.6 Many of these would apply to education as well. For example, one problem noted is the difficulty of defining the customer in a non-profit setting. Academic libraries would appear to have not one, but many customers, including students, faculty, university administrators, and indirectly, parents of students. The situation is further complicated by the fact that these various constituencies may compete for library services, and make contradictory demands on the library.

In the case of public universities, the library may have indirect or "hidden" customers, such as state governing bodies, and ultimately the public itself. In some instances, the library must decide whether it risks offending immediate customers such as students in order to fulfill its obligations to other less visible customers. These indirect customers complicate and challenge the validity of more simplistic notions of customer satisfaction and instruments used to measure it that might otherwise be perfectly adequate in commercial environments.

Thus, while many of the planning, organizing, marketing, budgeting, and related administrative activities and procedures in the business sector may have much in common with those in the non-profit sector, there are also important differences. One important difference lies in the area of goals. In a commercial environment, the goal is to maximize profits, which provides a relatively simple basis for decision making. In a non-profit setting, there may be many different goals that diverge from or even conflict with one another. 
Academic library administrators, for example, may decide that they want to make customer satisfaction their first priority. But the presence of employees with strong professional values and training who may have different ideas about the library's priorities and how best to go about achieving them makes implementing service quality potentially more difficult. Professional librarians may insist on making autonomous value judgments and decisions with regard to how they conduct their work. Many may have strong convictions about their work, and this sense of professionalism may conflict with management initiatives that are based on consumerism or commercialism.7

\section{The Semantics of Service Quality}

Part of the difficulty of adapting the service quality model to academic libraries stems from differing definitions of basic concepts like "quality" and "service." Advocates of the service quality model believe that quality service means surveying what the customer wants and finding the best way to provide it. Critics of the model define quality service as providing customers with what trained professionals (i.e. librarians) think they need. 8 In the service quality literature, recipients of service are commonly referred to as "customers." Critics have claimed that this debases the librarian's relationship to the user by suggesting that the knowledge which the librarian transmits is sold, as it might be in an information brokerage. Use of the word "customer" has also been criticized for implying that the user is a passive consumer of information, rather than being actively engaged in the learning process. 9

It may seem trivial to argue over language, but it is not only the language that is important but the concepts behind the language--what the language implies and how it is 
interpreted. To refer to a student as a "customer" may misinterpret the nature of the librarian/user relationship to the degree that it suggests a student can "buy" an education, without some degree of personal effort as well as assistance from the librarian. The process of acquiring a college education, part of which involves learning to use the library, can be hard work that involves sustained concentration and exertion that is not always comfortable or pleasant, and certainly not passive.10 This sometimes arduous process may conflict with the service quality goal of customer satisfaction and delight without some sort of adaptation of the model to an educational setting.

Perhaps the term "customer" or "client" might be better used to describe the nature of the relationship between the special librarian and the user. In a special library environment, the straightforward provision of information that the user wants appears to be much closer to the ethos of the service quality model. In a more complex environment such as academia, the librarian may have to interpret to some extent what is best for the user's needs, which is different from simply satisfying a user's wants.11

This distinction between wants and needs may seem like another semantic subtlety, but the difference has important implications. "Want" suggests a conscious desire for something, while need implies a greater degree of necessity or urgency which, if it is denied, may result in some kind of adversity or serious consequences to the person in need. A person may need something, but not necessarily be aware of it, thus making needs more difficult to detect than wants.12 That is, it is possible to determine what a library user wants by asking him, but when asked, that same user may not be able to articulate his needs, nor even always be aware of them. 
A user survey instrument such as Servqual or Servperf may thus be perfectly capable of revealing a user's wants, but not necessarily the user's needs. Yet because needs are seemingly more important than wants, it then becomes important to determine who decides what the user's needs are. Is the librarian in his or her role as professional capable of making such a determination?

\section{Competing Models of Service}

There is no easy answer to this question, but it is nonetheless important to make a distinction between wants and needs in order to point out that the service quality model may be less effective in determining user needs than wants. Academic librarians have traditionally used an older didactic model of service that is more or less based on the faculty model of teaching.13 In this model, the librarian has assumed the responsibility of anticipating what the students needs will be, which frequently call for the development of certain competencies in library research. These determinations are usually made in the context of some larger academic mission, such as to foster independent researchers capable of lifelong learning, or at least students capable of going on to successfully complete assignments at the graduate level.

Librarians must teach students these research skills so that they will learn to be self-sufficient, rather than simply providing the student with information by finding it for them. According to this didactic model of service, for the librarian to actually give students the answer would be to satisfy their immediate wants at the expense of their longer term needs. To do so would actually be a form of disservice, because in the reference transaction the student would learn little or nothing, thus reinforcing his 
dependence on the librarian and defeating the university's larger mission of creating independent learners. The definition of quality service in this older model is not so much the immediate satisfaction of user wants but serving users in a way that enhances their intellectual and personal development.

It is possible to cast this older model of didactic service in the language of business, using rhetoric similar to the service quality model. Instead of thinking of the student as "customer," upon graduation the student might be thought of as the "product" of the university (and indirectly, the library) and the "customer" then becomes the prospective employer.14 It is the responsibility of the librarian to help deliver a quality product to the employer, who is the ultimate determiner of quality. This definition of quality actually harkens back to the earlier roots of the quality improvement movement, which has its origins in attempts to improve the quality of the manufacturing process. 15

The fact that there are alternative models of service and that the service quality model may require some adaptation to non-commercial settings does not mean that it is not of value, and possibly considerable value, to libraries. As Moore and Kelly point out in an article on the utilization of the service quality model in the social work field,16 the acceptance of quality service concepts does not have to wait for the resolution of every incompatible aspect with non-profit organizations. Just because non-commercial environments and goals are more complex than in the business sector does not mean service quality concepts cannot be adapted if done with sensitivity to the differing context in which they will be implemented. Perhaps it might be useful to examine some ways in which the service quality model can be adapted to the complex environment of the library. 


\section{Adapting Service Quality Concepts to Reference Services}

The reference services department is one of the areas of the library most vulnerable to potential conflict between business-based service quality concepts and departmental policies and procedures, which are often based on the institutional mission of the university. Additionally, it is not always easy to implement basic tenets of quality service that rely on satisfying the customer's needs and wants when the customers themselves may not be entirely sure of what they are seeking. You cannot give customers what they want when they themselves are not sure. Customers cannot always be expected to have clearly formed preferences regarding the ever-changing and often bewildering array of electronic and paper products that they have to choose from. It is often left to the librarian to decide the best way to obtain the information the customer is seeking.17

If service quality concepts place the highest priority on delivering excellent service as perceived from the customer's point of view, than the user who comes to the reference desk requesting a product or service that is totally wrong for their needs presents a challenge to the librarian. A delicate process of redefining or renegotiating the customer's wants may be necessary.18 The librarian must forego the temptation to simply give the user what he wants, and instead employ tact and finesse in explaining why there may be a better alternative and helping the user rethink his needs in such a way that the user is not embarrassed or offended and the librarian does not create the impression that he or she is intellectually superior. There is always the risk that the librarian will not be successful in this endeavor, but he or she will at least have the 
satisfaction of knowing that that he or she acted out of a sense of professional ethics, rather than giving the user a quick fix.

Another potentially difficult situation is the user who comes to the reference desk with unrealistic expectations. A classic case is the student who is seeking "help" with an assignment, but who wants the librarian to find the information rather than having the librarian explain how he can search for the information himself. There are any number of reasons why students have such expectations. They may be based on an inadequate understanding of the educational mission of the academic library, in which the primary function of the librarian is seen as educating users by teaching them library research methods, rather than simply giving the information to them. The student may be in a hurry, or uncomfortable or unfamiliar with technology, or simply unmotivated to do the work himself.

Not all librarians will agree that simply providing the student with the information being sought is actually a form of disservice to him or her because the student will not have learned from having to do it himself.19 Yet those librarians who subscribe to the didactic service model of academic librarianship may feel that simply providing the student with the information may present an ethical conflict with their role as instructor and compromise the teacher-student relationship. This is a problem found not only in reference encounters with undergraduates but also with library students.20 Librarians who feel that training the user how to locate information is more important than solving the user's immediate problem may have difficulty in satisfying the user in service quality terms, much less delighting him or her. 
Despite the complexity of the situation, didactic model adherents do not necessarily have to give up their teaching function and thus risk weakening their association with the teaching faculty, thereby eroding their claims to faculty status.21 It is still possible for librarians to take advantage of the "teachable moment" in the course of the reference encounter and satisfy the user in a manner consistent with the service quality model. Indeed the potential solution may be found in how the librarian manages the reference encounter.

In any service encounter, the customer often brings a psychological "script" into the situation, which is a series of expectations based on the customer's previous experience in similar situations.22 Particularly in the case of undergraduates relatively new to an academic environment, the script they may possess may be based on their experience with other kinds of libraries such as public libraries. If the librarians in these encounters acted as "go fers" and promptly fetched whatever the student asked for, it is not unreasonable for students to expect the same response from an academic librarian.23

However, these early expectations that the customer brings to the service encounter are often tenuous and not held as firm convictions in the customer's mind.24 This provides the librarian with an opportunity to actively involve the customer in helping to create their own service, much as customers who use automated teller machines or who pump their own gas do. This may necessitate explaining how the customer's involvement will contribute to their own goal achievement and self actualization. Librarians can promote the benefits of greater customer involvement not only on an individual basis during the reference encounter, but also to larger audiences in user instruction classes. These classes present a particularly good opportunity for librarians to explain that 
although user satisfaction is a top priority, they have other important educational objectives that need to be addressed in reference transactions.26 It may be easier for a librarian to explain this more fully in a classroom setting then when pressed for time during a brief reference encounter.

By actively managing these service encounters and explaining to customers that parts of the service process that they consider to be annoying or inconvenient are actually done in their best interests, librarians help to enhance customer's service perceptions. Customers who realize that the librarian has their long term development in mind may tend to be more favorably disposed to that service.27 In effect, part of the service that the librarian should provide is to take into account the fact that the user's expectations may be unrealistic. The librarian then works with the user to adjust those expectations to reality. This process of adjusting user expectations is itself a service, and can be performed skillfully or poorly with corresponding results.

The service quality literature analyzes this process in some detail. Once the librarian believes that he or she has a clear grasp of the user's expectations, he or she can then check it with the user by a technique called mirroring.28 The librarian might say to the user "What you seem to be looking for is not just information about sibling rivalry, but also someone to help you search for it on the computer." Asking for this kind of informal confirmation from the user allows him or her to correct any assumptions on the librarian's part.

If the librarian discovers at this point that the user's expectation is in fact unrealistic, the librarian can then take several steps. One is to briefly explain why it may hinder the student's development if the librarian performs his search for him. Another 
step the librarian can take is to use a technique called "bone throwing," which involves compensating a customer for a perceived denial or loss of service.29 This means doing something for the student that shows the librarian empathizes with his or her situation, and wishes to help as much as possible without engaging in outright spoon-feeding. For example, the librarian might say "I'll perform a sample search while you watch, then you can try the real one."

Empathy is another critical element in the customer transaction. The librarian must convey a strong sense of understanding the user's situation. On a physical level, this includes exhibiting an intense interest in the customer's problem and nodding at appropriate intervals to indicate one understands the need the customer is expressing. At a verbal level, it involves the use of empathic responses that indicate to the user that he or she has been adequately understand on an emotional level. For example, in responding to the user who had been expecting the librarian to do the search for him, the response might be "I would feel frustrated too if my assignment was due tomorrow and I hadn't realized I'd have to learn to do much of the work myself."30 In the service encounter, customers respond not just to what is said or done, but how it is done.

If clarifying customer expectations, listening, and empathizing prove to be ineffective in satisfying the customer, there is another technique the librarian can use, called "diffusing." The librarian can say to the customer, "let me introduce you to my supervisor who can provide you with additional assistance." 31 This technique can be particularly useful in situations in which the customer has concerns about policy issues. By providing the customer with "a second opinion" from someone whom the customer regards as being of importance, the very act of receiving the additional attention can be a 
source of satisfaction to that customer. If the supervisor reiterates what the librarian has told the patron, hearing disappointing news from a second person can actually reassure the customer that he wasn't being singled out or that the first librarian's response was "personal."

At the broader level of policy, it would be extremely helpful to create a written policy for service quality. Such a policy would make it easier for librarians to avoid having to make personal judgments in serving users.32 The policy could make clear if different levels of service are to be provided to different types of users (e.g. faculty vs. students). It might also specify particular types of service situations or user requests along with appropriate staff responses to them.

\section{Adapting Service Quality to Access Services}

Reference services is perhaps the most obvious example of the necessity of having to adapt the service quality model to academic librarianship. There are other examples as well, such as access services. Some access services programs now feature services that enable faculty and students to request that books and articles be retrieved for them from the stacks by library staff, sometimes free of charge or for a modest photocopying fee. Such programs tend to be very popular with students at institutions that offer them, and it is not unusual for students to request that a dozen or more articles be retrieved for them at a time, enough to write a research paper with.

These document delivery programs are extremely useful and valuable services to certain portions of the campus population, such as faculty or distance learning students who cannot spend extended periods of time on campus. However, to extend the service 
to the larger student body, particularly undergraduates, may conflict with the overall educational mission of the university. There are several reasons why this is so.

To begin with, these services often simply assume that their customers already possess the necessary skills to locate a monograph or journal in the stacks. Yet this is not always so. The author has encountered students (typically undergraduates) who come to the reference desk claiming that they are unable to find not merely a particular volume or call number, but an entire call number range. Such students obviously need more experience in locating material in the stacks, which is a relatively easy procedure once one gets accustomed to how the LC classification system is arranged.

For undergraduates coming from small towns possessing only limited experience with the Dewey classification system of a small town public library, figuring out the LC classification system of a large research library may require some initial thought and effort. Library services that offer to retrieve stacks materials for students make it possible for them to attend college without having to learn this basic skill. To allow students to graduate without necessarily being able to locate a book in the library may run counter to broader educational objectives of creating independent, life-long learners.

Another important lesson that customers of these services are denied is learning the importance of serendipitous browsing. 33 Experienced scholars understand the value of this vital aspect of the research process. Typically, it is a process in which one goes to the stacks seeking a particular book or article, and is delighted to discover related and sometimes more valuable materials shelved in close proximity to the item that was originally sought. Students who use document retrieval services never learn how 
important this intellectual grazing activity can be, and as a result their research is impoverished and they themselves as researchers are potentially less effective.

Perhaps it might be possible to adapt these document delivery services so that they conflict less with the mission of educational institutions to produce effective scholars. One possibility might be to limit the services to graduate students or upperclassmen, who presumably would have been required to learn how to locate stacks materials in their earlier years. Another option might be to offer the service to students who have successfully passed a brief test of their ability to locate stacks materials. Such a test could be administered virtually using an online program developed for student shelvers. Moreover, it might enhance the value of the service in the student's eyes. It would allow those document delivery services to be offered, yet ensure that only qualified students would be using them. 34

\section{Modifying Service Quality Concepts for Collection Development}

One of the most basic assumptions of the service quality model is that only customers are capable of judging service quality, and that "all other judgments are essentially irrelevant."35 Yet, traditionally, librarians have selected books for the collection based not so much on what they believe students would want, but rather in anticipation of what they believe students will need for their studies. Librarians have thus tended to make choices that the students themselves might not make. Some indication of the kind of books students purchase may be found in examining a recent list of campus bestsellers. These tend to be a mix of genre fiction, pop psychology, and satirical humor.36 
Collection development librarians have made their selections based in part on the didactic model of service. With regard to developing the collection, this means that materials are chosen primarily on how well they support the instructional function of the library. This philosophy was summed up by Ross Atkinson, when he wrote "The academic library must therefore acquire material specifically intended for and used by undergraduates in fulfillment of its instructional function.”37

This would suggest that the service quality model with its demand-oriented approach to collection development, and the didactic service model with its instructional emphasis represent another potential source of conflict. The service quality model would attempt to increase usage and make the collection more responsive to immediate customer wants, regardless of other considerations such as quality or representativeness or didactic value. This approach deserves some consideration in light of usage studies such as the one done at the University of Pittsburgh, which indicated that a large percentage of library collections are infrequently or never used.38

At least in its pure form, however, the service quality model would suggest that the academic library be run something akin to a bookstore. Proponents of the model such as Berry frequently compare the library with the large bookstore chains, and suggest that libraries have much to learn from them if libraries are to survive. Given the book buying tastes of students, it would be difficult to rely solely on their opinions as to what should be made available or as to what constitutes quality. Many large research libraries even discourage purchasing such obviously didactic items as textbooks, even though they are frequently sought by students. Clearly, service quality concepts that emphasize demand and use principles with regard to developing the collection will require some adaptation 
to the academic library, with its long-standing emphasis on buying books that users should read, rather than what they actually do read. It may come down to a question of whether it is better for the library to try to cater to student's current interests, or whether it is necessary to try to expand student's interests by purchasing titles that are critically valued that may be more enduring.

The issue raised here goes beyond that of collection development to the larger issue of determining to what degree librarianship is a profession. In the medical profession, patients are not allowed to prescribe their own remedies. The patient relies on the professional judgment of the physician. Is the library user then capable of deciding what books should be purchased, or more generally, how the library should function in order to satisfy his wants or needs? The service quality model suggests that this may indeed be true. This then raises the further question of whether relying heavily on user opinion diminishes the role of the librarian's professional judgment in collection development in particular and managing the library more generally.39

The same issue was raised 35 years ago when sociologist William J. Goode questioned whether librarianship would ever become a profession. He wrote that in "serving" the user, the librarian needs to learn the user's wishes and try to satisfy them. But Goode warned that this can also deteriorate into simply giving users what they want, rather than attempting to educate the reader and thus fulfill a higher social obligation. Goode noted "This strain between the wishes and real needs of a clientele is perhaps to be found in all professions, but in established professions more often it is resolved by the professional's decision."40 The implication is that the librarian must not relinquish his or 
her professional judgment if he or she has any hopes of ever being considered a true professional.

Nonetheless, it may be possible for the librarian to better tailor the collection to the user's needs, without necessarily sacrificing professional judgment. One possible way to adapt the service quality model to academic library collection development would be to place more emphasize on use studies. This would appear prudent given the growing number of titles published and the decreasing size of collection development budgets. Some universities have begun to track circulation and interloan activity using automated systems with the intention of discovering which subject areas and titles are most in demand. This data could then be used to buy similar titles in related areas. Care would need to be taken so that this approach is not overemphasized and that some emphasis is still placed on developing other areas of the collection. The resulting collection would thus be more demand-oriented and reflective of local user needs without being entirely dictated by popular tastes. 41

Another way to achieve a more demand-oriented collection would be through the use of local citation analysis. This would involve examining the sources cited in dissertations and theses written at the particular library under study, and checking these sources against the library's holdings. Titles not part of the library's collection could then be added as necessary. This technique would appear to be particularly useful in satisfying customer needs at the graduate level.42 Various in-house measures of use such as marking volumes before reshelving them could also be utilized. 


\section{The Service Environment and the Academic Library}

The service quality model places great emphasis on "tangibles." These elements of the service environment include the overall condition and appearance of physical facilities, equipment, and staff. These seemingly external factors are important to customers because they make judgments about the overall quality of service based on them.43 Even such relatively intangible elements of the environment such as decor, style, color, art, and sound can be important to the customer.44

In his ALA address, Leonard Berry mentioned the importance of the overall service atmosphere to customers, and used the Tattered Cover Bookstore in Denver as an example. He uses the store as an example again in his most recent book on service. Berry specifically mentions that the store's antique furnishings and atmosphere make the customer feel at home. He quotes an employee who refers to " 151 comfy chairs and couches" as contributing to the overall ambiance that makes the store so popular with customers.45

The service quality emphasis on ambiance and atmosphere would suggest that there is no reason academic libraries need to be cold or institutional. Certainly more attention could be placed on ergonomic factors in computer workstations and study areas. But to furnish the library with overstuffed chairs and couches might actually constitute an imposition on some students. The reason for this is that students often come to the library not so much as to relax or unwind, but rather to work and study. For these students, "comfy" furniture might actually hinder their concentration when they would prefer to be alert and focused. This is not to imply that the furnishings need to be spartan or 
uncomfortable, but only to suggest that customers go to stores like Tattered Cover with different needs than the ones students bring to academic libraries.

One possible adaptation of the service quality emphasis on atmosphere might involve designating certain sections of the library as "comfort zones" that are furnished with an extra emphasis on comfort. Such areas could be furnished with lounge chairs, plush couches, and table lamps to give them a living room type of atmosphere. This would allow students the option of studying in whatever kind of environment they prefer, and possibly even shifting between them if they so desired. Students who feel simpler upright chairs and study tables help them do their work better would not be compromised by such an arrangement.

There is some evidence to suggest that functionality is an important aspect of ambiance in the eyes of library users, 46 and greater emphasis could be placed on orienting cues like signage. Special attention could be given to heavy traffic areas like reference. Restaurants, airports, and department stores have taken into account the psychology of waiting in line for service by providing distractions for customers, and academic libraries might do likewise. Would library users waiting in line be more satisfied if they could watch answers to frequently asked reference questions displayed on overhead video monitors? Some might even discover the answer to their question on the video, thus eliminating the need for having to wait in line any further.47 Using such instructive or diverting materials to engage customers who are waiting can help reduce customer frustration, as long as it is remembered that the activity chosen should offer a benefit itself and be somehow related to the subsequent service encounter. 
The area in which academic libraries can really learn much from bookstores is merchandising. Academic libraries typically treat their most valuable commodities, including books, journals and databases, as stock that is to be warehoused. These resources are seldom displayed in a way that makes them appear attractive or valuable to customers. As a result, the library loses an opportunity to enhance its value in the eyes of customers by not adequately displaying its wares. The customer cannot value what the library does not itself value.

Imagine how much more valuable the library might appear to a customer if the newly acquired books were prominently displayed. Carousels displaying books with dust jackets still on them and highlighted by track lighting might contribute to a more inviting environment then the current warehouse method that is so commonly used.48 New databases could be similarly showcased using some of the techniques that vendors at library conventions have used successfully to attract customers to their booths. Using the environment as a tool for increasing customer's current awareness is an important service that can only enhance the value of the library to the customer and potentially increase traffic in the library by conveying the image that the library has merchandise of value.

\section{$\underline{\text { Conclusion }}$}

This study has tried to point out some of the limitations and suggest some of the possibilities of the service quality model for academic libraries. Many of the limitations stem from the fact that the service quality model was originally developed for use in a commercial environment. This does not mean that the model is not without utility for the non-commercial environment of the academic library. Incorporating service quality 
concepts into the academic library setting is perfectly feasible and potentially valuable, but, as this study has tried to indicate, some adaptation may be necessary. The presence of an older competing model of didactic service may result in some resistance on the part of librarians who subscribe to this model. It is nonetheless possible for elements of both models to co-exist in a hybrid form that includes some of the best aspects of each model. This study represents an initial attempt at suggesting how the two models might be merged, but more research is needed in this area.

Some possible ways in which the service quality model might be adapted to various areas within the academic library have been discussed. Pure service quality tenets that insist that the customer is the sole judge of service or that satisfying customer wants is the key to quality service do not seem to fit readily with the academic library environment. The goals and methods of academe, and the relation of staff to customers is more complex than in the business and manufacturing settings that service quality concepts developed from. A basic paradox of academic librarianship that seems to emerge from this study is that by not always giving the student what he or she wants, the librarian is actually performing a service for the students by helping them to become more independent and encouraging them to move toward greater self-sufficiency.

Service quality concepts can make a significant contribution in this effort, because the service quality literature is especially rich in ways to prevent potentially disgruntled customers from going away dissatisfied. As this article has tried to show, librarians can learn much from adopting some of these techniques for relating to customers better. It is interesting to note that even though many librarians spend at least some part of their day involved in public contact, there is no component of library school training that gives 
librarians instruction in how to handle customers. Here too, librarians can learn much from the business sector. Many companies invest considerable time and effort in training staff that will be involved with the public, and such programs could serve as models for libraries and library schools interested in improving customer relations, and ultimately, customer satisfaction.

Other areas of the library besides reference services can benefit from adapting service quality concepts as well. The collection can be made more responsive to local user needs through the judicious use of user studies that strengthen the collection in heavily used areas but never at the expense of neglecting those areas that are less in demand. Academic libraries can also greatly improve the service environment by adopting some of the successful merchandising techniques employed by bookstores, so that both books and electronic resources are better displayed and brought to the attention of customers. Making the physical environment of the library appear more like a store and less like a warehouse may be as important as good customer relations in helping the customer appreciate the value of the library and its contents. It can thus be seen that the rich possibilities of adapting service quality concepts to the academic library environment may outweigh many of the limitations that the model currently poses in its pure or orthodox form.

1) Danuta A. Nitecki, "Changing the Concept and Measure of Service Quality in Academic Libraries," Journal of Academic Librarianship 22 (May 1996): 181-190. 
2) Leonard L. Berry, "Great Service Now: Framework for Action" (paper presented at the annual meeting of the American Library Association, New York, N.Y., July 1996)

3) Tibbett L. Speer, "Libraries from A to Z," American Demographics 17 (September 1995): 48-54.

4) Clifford Stoll, Silicon Snake Oil (New York: Doubleday, 1995), p. 188.

5) Marilyn Domas White and Eileen G. Abels, "Measuring Service Quality in Special Libraries: Lessons From Service Marketing,” Special Libraries 86 (Winter 1995): 36-45.

6) James E. Swiss, “Adapting Total Quality Management (TQM) to Government,” Public Administration Review 52 (July/August 1992): 356-362.

7) William H. Newman and Harvey W. Wallender, "Managing Not-For-Profit Enterprises," Journal of Library Administration 1 (Spring 1980): 87-97.

8) Bob Usherwood, "Libraries as a Public Service," Public Library Journal 7 (November/December 1992): 141-145.

9) Karyle S. Butcher, “Total Quality Management: The Oregon State University Library’s Experience," Journal of Library Administration 18 (1/2) 1993: 45-56.

10) Robert Pedersen, “The Perils of Total Quality Management: Bringing Business Rhetoric to Academe," The Chronicle of Higher Education 39 (September 23, 1992): B4. 11) Susan Jurow, "TQM: The Customer Focus" in Total Quality Management in Libraries: A Sourcebook ed. by Rosanna M. O'Neil (Englewood, Co: Libraries Unlimited, Inc., 1994): 18-19.

12) Andrew Green, “What Do We Mean By User Needs?” British Journal of Academic Librarianship 5 (2) 1990: 65-78. 
13) Thomas Seay, Sheila Seaman, and David Cohen, "Measuring and Improving the Quality of Public Services: A Hybrid Approach,” Library Trends 44 (Winter 1996): 464490.

14) William E. McGrath, "The Reappearance of Rankings: Reliability, Validity, Explanation, Quality, and the Mission of Library and Information Science," Library Quarterly 63 (2) 1993: 192-198.

15) George Keller, "Increasing Quality on Campus: What Should Colleges Do About the TQM Mania?" Change 24 (May/June 1992): 48-51.

16) Stephen T. Moore and Michael J. Kelly, "Quality Now: Moving Human Services Organizations Toward a Consumer Orientation to Service Quality,” Social Work 41 (January 1996): 33-40.

17) Jo Bell Whitlatch, "Customer Service: Implications for Reference Practice," The Reference Librarian 49/50 (1995): 5-24.

18) David K. Carr and Ian D. Littman, Excellence in Government: Total Quality Management in the 1990's (Arlington, Va.: Coopers and Lybrand, 1990) p.32.

19) James Rettig, "Can We Get There From Here?" in Evaluation of Public Services and Public Services Personnel ed. by Bryce Allen (Urbana, IL.:University of Illinois, Graduate School of Library and Information Science, 1991): 3-26.

20) Gayle J. Hardy and Judith Schiek Robinson, "Reference Services to Students: A Crucible for Ethical Inquiry,” RQ 30 (Fall 1990): 82-87.

21) John Lubans, Jr., "Teaching the User: Ethical Considerations,” The Reference Librarian 4 (Summer 1982): 89-98. 
22) J. Richard McCallum and Wayne Harrison, "Interdependence in the Service Encounter," in The Service Encounter: Managing Employee/Customer Interaction in

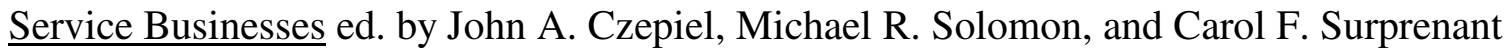
(Lexington, Mass.:Lexington Books, 1985): 35-48.

23) Bea Flinner, "Academic Libraries and Reference Ethics," The Reference Librarian 4 (Summer 1982): 151-155.

24) Christopher Millson-Martula and Vanaja Menon, "Customer Expectations: Concepts and Reality for Academic Library Services," College and Research Libraries 56 (January 1995): 33-47.

25) Barbara A. Gutek, The Dynamics of Service: Reflections on the Changing Nature of Customer/Provider Interactions (San Francisco: Jossey-Bass, 1995) p.147.

26) Janet Dangenais Brown, "Using Quality Concepts to Improve Reference Services" College and Research Libraries 55 (May 1994): 211-19.

27) Valarie A. Zeithaml, A. Parasuraman, and Leonard L. Berry, Delivering Quality Service: Balancing Customer Perceptions and Expectations (New York: The Free Press, 1990) p. 45.

28) Fred E. Jandt, The Customer Is Usually Wrong! (Indianapolis: Park Avenue Publishers, 1995) p. 39.

29) Ibid., p. 43.

30) Bernice B. Johnston, Real World Customer Service (Naperville, Illinois: Small Business Sourcebooks, 1996) p. 42.

31) Arlene Farber Sirkin, Is the Customer Always Right? (Towson, Md.: American Library Association/Library Video Networks, 1994) Videocassette, 23 minutes. 
32) Hardy and Robinson, "Reference Services to Students," p. 86.

33) James D. LeBlanc, "Classification and Shelflisting as Value Added: Some Remarks on the Relative Worth and Price of Predictability, Serendipity, and Depth of Access," Library Resources and Technical Services 39 (July 1995): 294-302.

34) Paul Heller and Stuart Kohler, "Take This Book and Shelve It!” College and Research Libraries News 57 (July/August 1996): 425-426.

35) Zeithaml, Parasuraman, and Berry, Delivering Quality Service p.16.

36) "What They're Reading on College Campuses," The Chronicle of Higher Education 42 (April 5, 1996): A36.

37) Ross Atkinson, "Old Forms, New Forms: The Challenge of Collection

Development," College and Research Libraries 50 (September, 1989): 507-520.

38) Allen Kent, et al., Use of Library Materials: The University of Pittsburgh Study (New York: Dekker, 1979).

39) George McMurdo, "User Satisfaction” New Library World 81, 958 (1980): 83-85.

40) William J. Goode, “The Librarian: From Occupation to Profession?” The Library Quarterly 31 (October, 1961): 306-320.

41) William A. Britten and Judith D. Webster, "Comparing Characteristics of Highly Circulated Titles for Demand-Driven Collection Development," College and Research Libraries 56 (July 1995): 313-318.

42) Margaret Sylvia and Marcella Lesher, "What Journals Do Psychology Graduate Students Need? A Citation Analysis of Thesis References," College and Research Libraries 56 (July 1995): 313-318. 
43) Kirk L. Wakefield and Jeffrey G. Blodgett, "The Importance of Servicescapes in Leisure Service Settings," Journal of Services Marketing 8, 3, 1994: 66-76.

44) Gregory D. Upah and James W. Fulton, "Situation Creation in Service Marketing," in The Service Encounter, p.257.

45) Leonard L. Berry, On Great Service: A Framework for Action (New York: The Free Press, 1995), p. 70.

46) Patricia Dewdney and Catherine Sheldrick Ross, "Flying a Light Aircraft: Reference Service Evaluation from a User's Viewpoint," RQ 34 (Winter 1994): 217-230.

47) Jean-Charles Chebat, Pierre Filiastrault, Claire Gelinas-Chebat, and Alexander Vanisky, "Impact of Waiting Attribution and Consumer's Mood on Perceived Quality," . Journal of Business Research 34 (November 1995): 191-196.

48) Carrie Goerne, "Now Book Browsers Can Munch Brownies as They Shop for Browning," Marketing News 26 (July 6, 1992):1-9. 